\title{
渋帯解消を考慮した渋滞区間判定モデルの構築と ファジィ推論の適用
}

\author{
松井 寛 $^{1} \cdot$ 藤田素弘 $^{2} \cdot$ 谷上敦亨 $^{3}$ \\ ${ }^{1}$ 正会員 工博 名古屋工業大学教授 社会開発工学科 (テ466名古屋市昭和区御器所町) \\ 2 正会員 工博 名古屋工業大学助教授 都市循環システム工学専攻 (テ466名古屋市昭和区御器所町) \\ 3 正会員 工修 首都高速道路公団 交通管制部 (テ100東京都千代田区霞ヶ関1-4-1)
}

\begin{abstract}
高速道路における渋滞情報は，その渋滞区間を明示した後，その通過所要時間や速度等を提供すること によって，道路区間ごとに大きく変化する交通状況をドライバーに明確に伝えることができることから， 各目的地までの経路別所要時間情報等が普及してきた状況に置いても依然として重要な意味を持つものと 思われる。しかし，現在提供されている渋滞情報は，その渋滞区間判定の定義においてドライバーが実際 に感じる渋滞の意識との間にずれが生じ情報の信頼性を失わせているとの指摘がある。本研究では, アン ケート調査により新たに渋滞解消の定義づけを行い, 先行研究の人間の知覚に基づく渋滞の定義に組み込 んだモデルとファジィ推論を適用するモデルを構築し，より信頼性及び操作性に優れた渋滞区間判定モデ ルについて考察した.
\end{abstract}

Key Words : information system for drivers, fuzzy reasoning, traffic congestion

\section{1.はじめに}

高速道路におけるリアルタイムな交通情報には， 各目的地までの経路別所要時間情報, 地点ごとの渋 滞情報，道路工事情報等が提供されているが，中で も, 渋滞区間を明示して，その通過所要時間や速度 等を提供する渋帯情報は，道路区間によって大きく 変化する交通状況をドライバーに明確に把握させる ことによって，渋滞緩和や経路誘導，事故の未然防 止など様々な効用が期待される.

しかし，従来の渋滞区間判定に用いられている渋 滞の定義のほとんどは, 速度という要因のみで与え られており ${ }^{1), 2)}$ ，これによる渋滞区間情報とドライ バーが実際に感じる渋滞意識との間にずれが生じて いることも指摘されてきている．このずれは交通情 報の持つ本来の利便性・信頼性を著しく低下してい るもの亡考えられ，これを解消し渋滞情報の本来の 機能を回復する必要があると思われる.

著者ら は既にこのずれを解消することを目的と した研究を行い, 心理学の知覚研究分野におけるブ ロッホの法則を適用することによって人間の知覚に 基づく渋滞の定義を導くとともに高速道路上におけ る車両感知器デー夕に適用可能なモデルの構築を行 いその実用可能性を示した。 しかし，この定義を実 際の交通観測データをもとにリアルタイムに運用し
ようとするときには，次節で説明するように幾つか の課題が残された.よって本研究では，それらの点 に対処することによってより汎用性の高い渋滞判定 モデルの構築を試みるものである.

\section{2. 従来の研究と本研究の概要}

近年, ITS(Intelligent Transport Systems)を代表とす る高度交通情報提供に関して積極的な研究がなされ ているが, その多くは高速道路の渋滞を物理的に取 扱ったもの ${ }^{4)}$.5 や経路誘導情報に対するドライバー

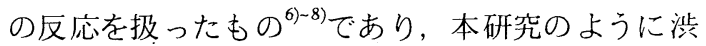
滞情報を提供する際の渋滞区間の特定化をドライバー

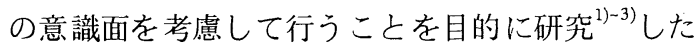
ものとはなっていない，文献1）,2）においては， アンケート調査によってドライバーの渋滞意識を聞 いているものの，いずれも 1 ，で述べたように，従 来の渋滞の定義は速度 $40 \mathrm{~km} / \mathrm{h}$ 以下を渋滞とするよう な速度のみによるものであった。

これに対して，著者ら ${ }^{3)}$ が行った人間の知覚に基 づく渋滞の定義（以下，知覚渋滞定義）は，渋滞を 速度とその継続時間との関係から表現し，よりドラ イバーの渋滞意識を反映したものとして図ー 1 のよ うに得られた。

しかし，この定義は渋滞解消についてはとくに考 


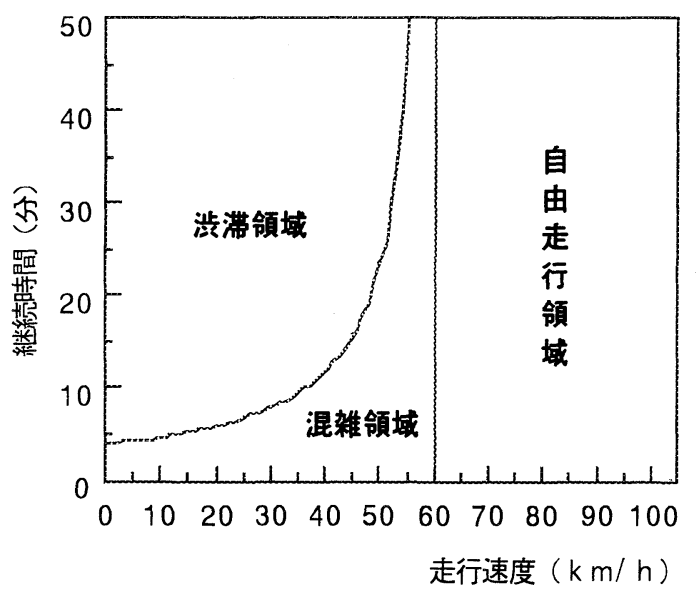

図-1 人間の 知覚に基づく渋滞の定義

慮されておらず，例えば，渋滞と判定された区間 に非渋滞区間（速度 $60 \mathrm{~km} / \mathrm{h}$ 以上の区間）が挟まれる ような場合, これを含めて 1 つの渋滞と判定するか,

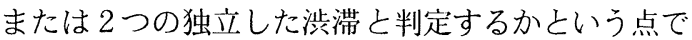
はこの定義だけでは判断できないことが分かった.

そこで本研究では, 文献3）と同様にアンケート 調査によって渋滞解消についての定義づけを行い, これを上記の知覚渋滞定義に補うことでこの点を改 良した渋滞解消を考慮した趽滞判定モデルを構築す る.このモデルは知覚渋滞定義と渋滞解消の定義を 厳密に利用するいわば決定論的なモデルである。こ のモデルは渋滞判定の基本的なモデル構造と心理学 的な見地からの妥当性を確認する上で重要であるが, その定義の設定の過程において, 被験者から得られ た多くの渋滞意識データのバラツキを考慮せず平均 值として利用していることや，高速道路上の車両感 知器の配置等, 様々な変化に対応して道路管理者側 の経験的知識が反映できるようにはなっていないと いう課題が残される.よって次に，これらの点を考 慮に入れることを目的に, 渋滞判定モデルへのファ ジィ推論の適用を試みるものである.

本研究の構成は以下の通りである. 3。では，ア ンケート調査により渋滞解消の定義を導き，それを 知覚渋滞定義亡統合して渋滞解消を考慮した渋滞判 定モデルを構築し, その判定結果と従来モデルによ る判定結果を比較する．4 。では，ファジィ推論を 利用したファジィ推論型渋滞判定モデルを構築する. さらに，それぞれの判定結果を比較検証しその妥当 性を検証する。
2. でも述べたように，文献3）の知覚漠滞定義 は渋滞解消については説明されておらず，渋滞区間 に非渋滞区間（速度 $60 \mathrm{~km} / \mathrm{h}$ 以上の区間）が挟まれる ような場合，これを 1 つ渋滞とするか 2 つ独立 した渋滞とするかという点で問題が生じた．このよ うなことは渋滞の延伸時, 定常時, 解消時に限らず そのときの䠈滞の道路区間の占有状況によって生じ る問題であるが，これを解決するため，知覚渋滞定 義を導いたのと同様にアンケート調査により渋滞解 消について定義つけを行い，これを知覚渋滞定義に 補うことで渋滞解消を考慮した渋滞判定モデルの構 築を試みる.ただし，ここではデータのばらつき等 については考慮されない。

\section{(1)渋滞解消の定義}

渋滞解消の定義を導くために，以下のような渋滞 情報についての評価アンケート調査 ${ }^{10), 11)}$ を行った. アンケート調査は, 平成 5 年11月 3 日（祝），4 日 （木）の午前 10 時〜午後 5 時まで，名神高速道路下 りの養老サービスエリア内におけるドライバーを対 象に，(1)個人属性，(2)渋滞解消の定義，(3)渋滞情報 評価の 3 つ項目について調査員の聞き取りによっ て行った. 分析の結果祝日と平日の渋滞意識には差 が見られなかったので，以下ではここで得られた両 日の有効サンプル634件の上記の質問(2)につての デー夕をもとに渋滞解消についての定義づけを行う.

質問(2)の内容は，まず被験者に与える渋滞の条件 について図ー 1の渋滞領域における渋滞の程度 (左 上方に行くほど渋滞が激しくなる）が分散すること を考慮して， $10 \mathrm{~km} / \mathrm{h}$ が10分，20分または40分続いた とき， $30 \mathrm{~km} / \mathrm{h}$ が 20 分または 40 分続いたとき， $50 \mathrm{~km} /$ hが40分続いたとき，の6ケースを用意して，被験 者にはその内の 1 ケースについてそれぞれ回答して もらった．質問は，(1) $10 \mathrm{~km} / \mathrm{h}$ 以下のスピードが10分 続いている渋滞にあなたが巻き込まれたとすると， その渋滞が解消したかなと思い始めるスピードは, スピードが何 $\mathrm{km} / \mathrm{h}$ に戻ったときてすす？(2)そのスピー ドが何分続けば解消したと確信しますか?，の 2 項 目である.この質問の回答の妥当性については以下 の分析で確かめるものとする.

ここでは，知覚渋滞定義を導いた方法と同様にし て，このアンケートデータを上記の渋滞条件別，及 び渋滞解消開始速度 $\left(V_{\mathrm{s}}\right)$ 別に解消確信継続時間 $\left(\mathrm{T}_{\text {? }}\right)$ の平均值を求め, その関係を図 -2 に示し た。 


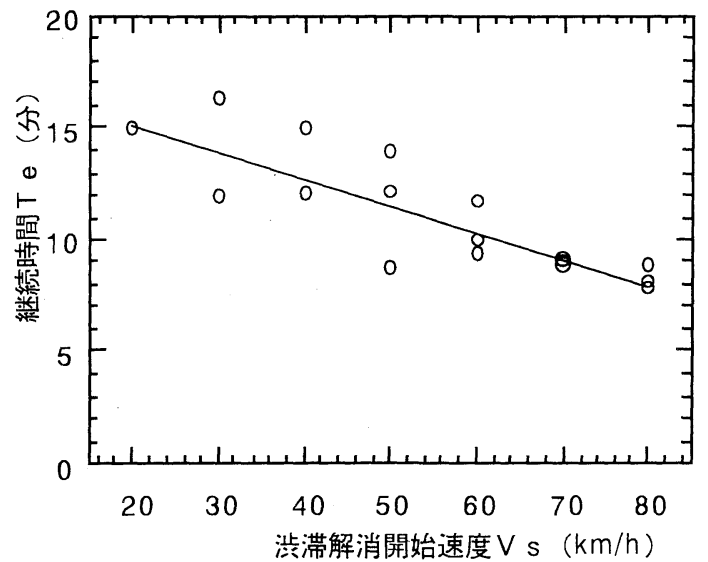

図-2 渋滞解消の定義

この図から， $V_{s}$ が大きいほど， $T_{2}$ が小さいこ とがわかり，さらにこの関係を回帰分析したところ， 以下のような回帰式が得られた。

$$
\begin{gathered}
T_{e}=17.7-0.12 V_{s} \\
(\mathrm{R}=0.85, \text { デー夕数 } 17 \text { 個 })
\end{gathered}
$$

ここでは, 他の関数形, 特に知覚渋滞定義と同様な 双曲線関数についても分析したが上記の関数が最も 相関が高かった. さて, 図ー2 はそれぞれの速度が 回帰線の継続時間以上続けば渋滞解消とドライバー が知覚することを示している．ここで渋滞解消開始 速度を刺激強度とすれば，渋帯解消を知覚するとき の刺激強度亡継続時間の関係は逆比例関係となって いる. この逆比例関係は一般的な視覚, 聴覚, 嗅覚 等の知覚に対する, 刺激と継続時間の関係において も同様に観測されているものである。また，この式 の相関係数は 0.85 であることから, 式 (1) は啮滞 解消の知覚関係を十分表しているといえる.この式 をもって渋滞解消の定義とするが，次節ではこの定 義を知覚渋滞定義に組み込んだ, 渋滞解消を考慮し た渋滞判定モデルについて説明する.

なお，図一 2 からは $20 \mathrm{~km} / \mathrm{h} か ゙ 15$ 分続けば渋滞解消 という状況も読みとれるが，これは設定された渋滞 条件が, $10 \mathrm{~km} / \mathrm{h}$ が40分続いたとき，というものに解 答した人の少数のデー夕の平均值であるといえる. この渋滞解消定義は次節の判定モデルにおいては速 度 $60 \mathrm{~km} / \mathrm{h}$ 以上の領域で基本的に利用されるため, 上 記の状況はほとんど影響しないと言える。

また，ここでは，車種別，走行速度別においても 図一 2 と同様なものを作成したが特に違いは見られ なかった。

\section{(2)渋帯解消を考慮した渋帯判定モデル}

渋滞解消を考慮した渋滞判定モデルは知覚渋滞定 義に渋滞解消の定義を組み込むものである．ここで はまずその知覚渋滞定義による渋滞判定について整 理する.

車両感知器によって区分された道路区間において, 速度 $60 \mathrm{~km} / \mathrm{h}$ 以下が連続する区間 $\mathrm{i}(=1 \sim \mathrm{n})$ の感知器デー 夕（区間距離Di $(\mathrm{km})$, 区間平均速度 Vi $(\mathrm{km} / \mathrm{h}))$ を用い て渋滞判定することを考えて, 知覚渋滞定義式を整 理すると以下の式が得られた .

$$
\sum_{i=1}^{n}\left(D_{i} K_{i}\right)>4(\mathrm{~km})
$$

$$
\begin{gathered}
こ こ に, D i ： \text { 区間 } \mathrm{i} \text { の距離 }(\mathrm{km} / \mathrm{h}) \\
K_{i}=\frac{60}{v_{i}}-1
\end{gathered}
$$

式(2)のD ${ }_{i} K_{i}$ は，渋滞に巻き込まれている時間 を, 速度 $60 \mathrm{~km} / \mathrm{h}$ で走行したときの仮想距離と1 n区 間全体の平均速度で走行した実距離との差を示すも のである．具体的には，(a)全道路区間から $60 \mathrm{~km} / \mathrm{h}$ 以 下が連続している渋滞判定対象区間を抽出し，その 各区間iにおいて $\mathrm{D}_{\mathrm{i}} \mathrm{K}_{\mathrm{i}}$ 值を計算し，それらを足し あわせて $4(\mathrm{~km})$ 以上になれば，その連続する $60 \mathrm{~km} / \mathrm{h}$ 以下の区間を渋滞として判定する。 (b)ただし, 渋滞 判定対象区間内に $60 \mathrm{~km} / \mathrm{h}$ 以上の区間が 1 つの場合は それを含めた対象区間とし，2つ以上連続する場合 は前後を別の対象区間とする.

この(bの操作は知覚渋滞定義とは関係のない便宜 的な操作であるが, これは, 地点データとしてしか 得られない感知器データの信頼性の問題, すなわち 一ヶ所のデータだけから渋滞解消を判断するのを避 ける目的でおこなうということと, 次のようなドラ イバーの意識むまた考慮されたものである.

すなわち実際の高速道路の非定常な渋滞流におい ては, 短期間中に速度の上昇, 低下が繰り返される ことが少なくなく, したがって速度が一度上がった からといってドライバーが直ちに渋滞解消を認識し ないという意識傾向を考慮した操作である.

本研究ではこういった操作もドライバーの渋滞解 消意識に基づいて行うことによって総合的な渋滞の 定義方法を考えていくものである. したがって，本 研究における渋滞解消の定義は, 知覚渋滞定義にお いて渋滞と判定された後に再び $60 \mathrm{~km} / \mathrm{h}$ 以上になった 区間を対象にして解消地点を判定し，それによって 渋滞区間を特定する.

この判定方法を図ー 3 の例をもとに説明する. ここで,

$D_{i}{ }^{\prime} \quad$ : 感知器の勢力範囲 (区間距離) 


\begin{tabular}{|c|c|c|c|c|c|c|c|c|c|c|}
\hline 区間No & A & B & C & D & $E$ & F & G & $\mathrm{H}$ & I & J \\
\hline 距離 & 1.95 & 1.95 & 2.00 & 1.55 & 4.14 & 1.87 & 1.55 & 2.23 & 2.03 & \\
\hline $6: 40$ & 97.4 & 98.9 & 98.6 & 75.8 & 68.0 & 80.4 & 70.0 & 73.1 & 72.3 & 73.9 \\
\hline $6: 50$ & 99.3 & 100.4 & 99.7 & 67.7 & 68.2 & 69.3 & 69.2 & 72.4 & 22.0 & 75.4 \\
\hline 7:00 & 95.1 & 96.2 & 93.6 & 49.1 & 35.3 & 66.7 & 66.7 & 63.1 & 24.2 & 71.9 \\
\hline $7: 10$ & 98.3 & 98.2 & 98.3 & dog & 3 & dis & 66 & 265 & 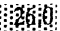 & 76.1 \\
\hline $7: 20$ & 98.6 & 97.2 & 96.5 & $6 \beta^{2}$ & 40 & 67.6 & 44.4 & 26.4 & 49 & 71.9 \\
\hline $7: 30$ & 98.1 & 97.8 & 94.4 & 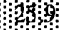 & 30 & $8 ;$ & 78 & 61.5 & 4 & 74.0 \\
\hline $7: 40$ & 99.8 & 100.6 & 93.0 & (I) & 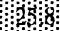 & Spo & 8 & 63.6 & 27.8 & 76.1 \\
\hline $7: 50$ & 98.4 & 98.6 & 93.8 & 4 & 9 & Ko & 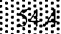 & $4 \mathrm{sin}$ & 5119 & 69.8 \\
\hline $8: 00$ & 100.9 & 97.7 & 82.1 & 19 & 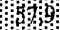 & $\%$ & 36 & 30 & 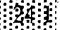 & 73.8 \\
\hline $8: 10$ & 100.8 & 98.9 & 84 & 645 & 角 & 3 & $7 \%$ & 43 & 彺! & 71.1 \\
\hline $8: 20$ & 97.3 & 97.8 & 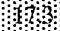 & 3 & 46 & & 3 & (j) & : & 71.1 \\
\hline $8: 30$ & 96.3 & 97.2 & \% & 4 & 19 & & ${ }^{2} 46$ & 08 & $24 \mathrm{E}$ & 68.0 \\
\hline $8: 40$ & 99.0 & 99.7 & 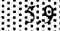 & $2 \alpha$ & 5 & $\% 4$ & 36 & 44 & 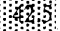 & 63.6 \\
\hline $8: 50$ & 97.4 & 97.5 & & $\%$ & 3 & (f) & $y^{\prime}$ & $m_{1}$ & 45 & 63.6 \\
\hline $9: 00$ & 96.1 & 96.2 & 11 & 90 & 8 & 61.5 & 29.1 & 56.2 & 47.1 & 64.1 \\
\hline $9: 10$ & 96.0 & 97.0 & \% & 44 & 65 & 74 & 62.5 & 66.6 & 36.9 & 74.0 \\
\hline $9: 20$ & 92.5 & 93.5 & 8 & 20 & 9 & 66.5 & 59.8 & 60.2 & 60.8 & 69.1 \\
\hline $9: 30$ & 95.5 & 82.4 & 8 & $2 \%$ & 9 & 66.6 & 60.2 & 60.0 & 59.6 & 69.4 \\
\hline $9: 40$ & 99.4 & 1996 & 89 & $\xi \xi^{\prime}$ & 60.3 & 72.0 & 58.8 & 64.8 & 55.2 & 70.9 \\
\hline $9: 50$ & 95.4 & 6 & 6 & 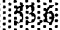 & 9889 & 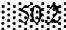 & 61.7 & 64.3 & 28.3 & 71.8 \\
\hline 10:00 & 92.7 & $1 \lg ^{\prime}{ }^{\prime}$ & 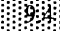 & 43 & 46 & 4 & 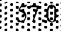 & 63.4 & 34.3 & 69.2 \\
\hline $10: 10$ & 98.6 & 4 & So & $3 \%$ & 隻 & ( & 4 & 61.9 & 44.7 & 69.2 \\
\hline $10: 20$ & 98.9 & 65 & 13 & $\alpha 6$ & 64.7 & 43.9 & 57.3 & 61.1 & 40.2 & 67.7 \\
\hline $10: 30$ & 98.6 & 88.5 & 9 & 64 & 63.1 & 56.1 & 58.4 & 60.0 & 33.7 & 69.1 \\
\hline $10: 40$ & 93.5 & 94.7 & 129 & 40 & 465 & 67.0 & 4 & $z$ & $\left.x_{4}\right)$ & 70.2 \\
\hline $10: 50$ & 97.5 & 96.5 & 33 & 64 & 458 & 446 & i & 8 & $4 \%$ & 66.2 \\
\hline $11: 00$ & 95.6 & 96.8 & 32.7 & 36.6 & 48.5 & 64.0 & 30.3 & 38.3 & 42.7 & 69.9 \\
\hline $11: 10$ & 97.1 & 96.7 & 89.2 & 33 & 9 & 46 & 44 & 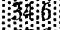 & 84 & 70.6 \\
\hline $11: 20$ & 97.4 & 98.9 & 92.7 & 4 & 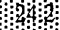 & $6 x$ & th & 8 & 68.9 & 68.4 \\
\hline $11: 30$ & 98.1 & 100.5 & 93.4 & 73.0 & 36.0 & 688 & 59.4 & 65.8 & 72.5 & 66.9 \\
\hline $11: 40$ & 98.9 & 99.0 & 92.7 & 69.0 & 493 & 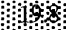 & 63 & 65.6 & 65.2 & 69.8 \\
\hline $11: 50$ & 93.5 & 93.9 & 93.0 & 77.8 & 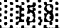 & 76.8 & 69.8 & 74.1 & 73.8 & 78.2 \\
\hline
\end{tabular}

図一 4 従来モデルによる判定結果

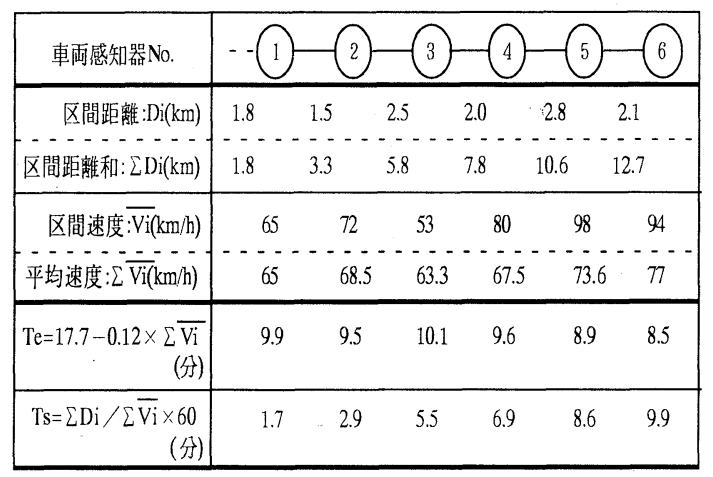

図－３渋滞解消地点の判定方法例

$\Sigma D_{i}^{\prime} \quad$ : 渋滞判定後再び $60 \mathrm{~km} / \mathrm{h}$ 以上となる最初の感 知器区間をNo.1として計算される $D_{i}^{\prime}$ の総 和

$\bar{V}_{i}:$ 各感知器の勢力範囲の区間平均速度

$\Sigma \bar{V}_{i}:$ 感知器区間No.1からの $\overline{V_{i}}$ の平均速度

$T_{e}:$ 解消確信継続時間 (式(2))

$T_{S}:$ 実際の走行時間（分）

\begin{tabular}{|c|c|c|c|c|c|c|c|c|c|c|}
\hline 間No & $\bar{A}$ & $\bar{B}$ & $\mathrm{C}$ & $\bar{D}$ & $\bar{E}$ & $\bar{F}$ & $\bar{G}$ & $\overline{\mathrm{H}}$ & I & $J$ \\
\hline 距離 & 1.95 & 1.95 & 2.00 & 1.55 & 4.14 & 1.87 & 1.55 & 2.23 & 2.03 & 1.90 \\
\hline $6: 40$ & $\overline{97.4}$ & 98.9 & 98.6 & 75.8 & 68.0 & 80.4 & 70.0 & 73.1 & $\overline{72.3}$ & 73.9 \\
\hline $6: 50$ & 99.3 & 100.4 & 99.7 & 67.7 & 68.2 & 69.3 & 69.2 & 72.4 & 22.0 & 75.4 \\
\hline $7: 00$ & 95.1 & 96.2 & 93.6 & 49.1 & 35.3 & 66.7 & 66.7 & 63.1 & 24.2 & 71.9 \\
\hline $7: 10$ & 98.3 & 98.2 & 98.3 & 猚 & ; & digioj: & ) & 接 & 角 & 76.1 \\
\hline $7: 20$ & 98.6 & 97.2 & 96.5 & 90 & 20 & 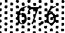 & & 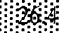 & Q & 71.9 \\
\hline $7: 30$ & 98.1 & 97.8 & 94.4 & 9 & (j) & $3 y$ & 9 & 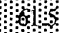 & 9 & 74.0 \\
\hline $7: 40$ & 99.8 & 100.6 & 93.0 & 3 & 85 & 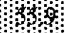 & 5 & 察 & deg & 76.1 \\
\hline $7: 50$ & 98.4 & 98.6 & 93.8 & 1 & 徨 & 3 & 94 & 阵 & 49 & 69.8 \\
\hline $8: 00$ & 100.9 & 97.7 & 82.1 & 3 & 的 & 4 & 49 & 3 & 躍 & 73.8 \\
\hline $8: 10$ & 100.8 & 98.9 & is & 4 & 5 & 360 & 34 & 流 & 9 & 71.1 \\
\hline $8: 20$ & & 97.8 & 19 & 31 & 696 & (j) & 94 & 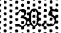 & 㱠 & 71.1 \\
\hline $8: 30$ & 96.3 & 97.2 & 8 & 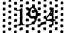 & (y) & (1) & 6 & 38 & 44 & 68.0 \\
\hline $8: 40$ & 99.0 & 99.7 & 8 & 3 & 5 & 440 & 9039 & 3 & 4 & 63.6 \\
\hline $8: 50$ & 97.4 & 97.5 & \$ & 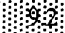 & (q) & 3 & 33 & 4 & 解 & 63.6 \\
\hline 9:00 & 96.1 & 96.2 & 19 & ) & $5 \mathrm{~g}$ & 3 & 20 & \% & 44 & 64.1 \\
\hline $9: 10$ & 96.0 & 97.0 & \% & 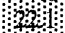 & 84 & 3 & 62.5 & 66.6 & 36.9 & 74.0 \\
\hline 9: & & & 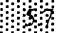 & & 89 & 66.5 & 59.8 & 60.2 & 60.8 & \\
\hline $9: 30$ & 95.5 & 82.4 & 倠 & 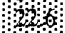 & 4 & 66.6 & 60.2 & 60.0 & 59.6 & 69.4 \\
\hline $9: 40$ & 99.4 & 90 & 9 & 1 & 603 & 72.0 & 58.8 & 64.8 & 55.2 & 70.9 \\
\hline 50 & 95.4 & 8 & \% & $3 \%$ & (9) & ; & 的 & 64 & 283 & 71.8 \\
\hline & 92.7 & 9 & 8 & 3 & (y) & 梅 & 93 & to & 3 & 69.2 \\
\hline 10 & 98.6 & (j) & i & 30 & $4 y^{3}$ & 9 & 345 & ig & jaj & 69.2 \\
\hline & 98 & 5 & 19 & i & (9) & 49 & 3 & 的 & 40 & 67.7 \\
\hline & 98.6 & 88.5 & $1 \%$ & 4 ; & 3 & 物 & & 6 & 33 & 69.1 \\
\hline & 93.5 & 94.7 & ( & $x$ & (3pip & gio & 4 & 3 & 9 & 70.2 \\
\hline & 97.5 & 96.5 & 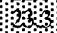 & S & S5: & (j) & 51 & \% & 97 & 66.2 \\
\hline & 95.6 & 96.8 & 30 & 6 & (y) & (x) & 30 & (jo & ig & 69.9 \\
\hline & 97.1 & $96: 7$ & 89.2 & 39 & (a) & (j) & 3 & (9) & 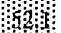 & 70.6 \\
\hline 20 & 97.4 & 98.9 & 92.7 & & (3) & 34 & (9) & (4) & 68.9 & 68.4 \\
\hline & 98.1 & 100.5 & 93.4 & 73.0 & 36.0 & 68.8 & 59.4 & 658 & 72.5 & 66.9 \\
\hline & & 99.0 & 92.7 & 69.0 & (3) & (9) & ; & 65.6 & 65.2 & 69.8 \\
\hline $11: 50$ & 93.5 & 93.9 & 93.0 & 77.8 & : & 76.8 & 69.8 & 74.1 & 73.8 & 78.2 \\
\hline
\end{tabular}

図ー5 渋滞解消を考虑した渋滞判定モデル による判定結果

上記の定義は，速度が $60 \mathrm{~km} / \mathrm{h}$ 以下の渋滞区間が続 いた後で $60 \mathrm{~km} / \mathrm{h}$ 以上に初めて上がった区間を始点と して $60 \mathrm{~km} / \mathrm{h}$ 以上の速度の区間の平均速度 $\Sigma \bar{V}_{i}$ を求め る. 次にその $\Sigma \overline{V_{i}}$ の速度で $T_{e}$ 分走行できていれば渋 滞は解消した之判定するものであり, 実際には $\Sigma \bar{V}_{i}$ の速度で走行した時間 $\left(T_{s}\right)$ が $T_{e}$ より大きくなれば よいことになる。またこのとき，渋滞解消地点は $60 \mathrm{~km} / \mathrm{h}$ 以上になった地点（ここでは感知器No.1）と する. 渋滞解消が判定された後, 再び60 km $/ \mathrm{h}$ 以下に 速度が下がった場合は, 新しくその区間から知覚渋 滞定義の判定プロセスを行う.

また, 渋滞判定後, $60 \mathrm{~km} / \mathrm{h}$ 以上に上がった後で渋 滞解消と判定される前に再び $60 \mathrm{~km} / \mathrm{h}$ 以下に戻ればそ の $60 \mathrm{~km} / \mathrm{h}$ 以上の区間も含めて一つの大きな渋滞と判 定とする.

\section{(3)判定結果の比較}

次に，渋滞解消を考慮した渋滞判定モデルによる 判定結果亡従来モデル（知覚渋滞定義の(a)(b)の手順 のうち便宜的操作である(b)は行わないもの）による 判定結果の比較を図ー4，5に示した。渋滞区間判 定に用いるデー夕は感知器速度デー夕を用いる. 
その利用されるデー夕の時刻は図一 $4 ， 5$ における 図左端の時刻から過去数分間に観測されたもので, その時間帯における平均速度をそれぞれのA J区間 のデータで算定して使用する。これはドライバーが 実際の状況において情報を橴滞前に前もって受ける ときの状況を考慮したものである．また，その速度 デー夕は通常過去 5 分間の平均速度デー夕が利用さ れるが, 本研究ではその感知器デー夕の集計方法を 改良した推定実測値を用いた，推定実測值は，過去 のデータを用いるが，過去 5 分間に固定せず実際に 車が測定区間内を通過する時間のデー夕を利用して 平均するものである ${ }^{9)}$ 。また，この感知器デー夕は 平成 5 年 5 月 26 日(水)の名神高速道路上り大垣I.C. 〜一宮I.C. 間のものを使用した，従来モデルによる 判定結果と渋滞解消を考慮した渋滞判定モデルによ る判定結果を図ー4，5に示した。

両図を比較すると明らかなように, 知覚渋滞定義 のみを扱った従来モデルよりも本研究の渋滞解消を 考慮したモデルの方がより多くの箇所を渋滞之判定 する傾向が見られるが，従来モデルに比べて中抜け は少なく安定した判定をすることが分かる．雨者の 比較で従来モデルで渋滞でなく本研究のモデルで渋 滞と判定された箇所についてはいづれも $60 \mathrm{~km} / \mathrm{h}$ 前後 の速度となっており, 通常80 100 km/hを平均速度と して走行しているドライバーによって，特にC E区 間にかけて強い渋滞を経験した後では，その後の 60km/hはいつまた速度が低下してもおかしくない不 安定な状態であると判断すれば渋滞解消を考慮した 本モデルの妥当性が理解できるものと思われる．ま た, 実際に従来モデルの中抜け状況を見ると, 前後 の状態から一つの渋滞と判断してもいいようなもの とか, また9:00の交通状況などのようにF区間に $60 \mathrm{~km} / \mathrm{h}$ 以上の区間がまぎれているのでそれ以降は渋 滞と判断されていないが，その隣のG区間では $29 \mathrm{~km} / \mathrm{h}$ の比較的渋滞度の高い区間がはいってその後 も $60 \mathrm{~km} / \mathrm{h}$ 以下の速度が続くような箇所があり，この ような箇所では特に渋滞解消を考慮したモデルが妥 当であると思われる. また, 11:00の従来モデルの 結果を見ると, $40 \mathrm{~km} / \mathrm{h}$ 未満の区間が長く続くにもか かわらず渋滞と全く判定されていないが，これは，

$\mathrm{F}$ 区間に一つだけ $60 \mathrm{~km} / \mathrm{h}$ 以上の区間が入ったためで

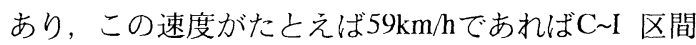
は知覚渋滞定義においても橴滞と判断されるところ である.

さらに，1つの車両感知器について縦(時系列)方 向に湶滞区間を見ても，図－4 は中抜けが多く不連 続だが，図－5はほとんど見られない．このことか ら，渋滞情報を提供する道路管理者側にとっても渋
滞情報の泳滞区間を常に変動させて提供するよりは 都合の良い結果といえよう。

\section{(4)本モデルの課題とファジィ推論}

さて, 本渋滞解消を考慮した渋滞判定モデルは, 渋滞意識を速度と継続時間によって一次関数として 表現することによって，心理学的な見地からこの定 義の有効性を確認するとともに，その定義になんら 変更を加えることなく，各道路区間の速度デー夕を 適用したものといえるが，さらにより汎用性の高い モデルを構築する上では以下のような問題が残され る.

すなわち，(1)その定義はアンケート集計結果の平 均值から導かれており，渋滞意識におけるアンケ一 卜回答のバラツキを考慮していないこと，(2)知覚渋 滞定義と渋滞解消定義をそのまま適用する上記の判 定モデルでは柔軟に道路管理者側の経験を導入する ような構造にはなっていない点などである。

これらのうち特に(2)の点は実際の渋滞判定におい て以下のような状況を示す.

図一 4，5の判定例で見たように， $60 \mathrm{~km} / \mathrm{h}$ 以下 の渋滞区間に挟まれた，60km/h以上の道路区間Aを， 前後の渋滞区間に含めるかどうかを判断する際, た とえば，その区間Aの前後の区間が $10 \mathrm{~km} / \mathrm{h}$ の渋滞て 区間 $A$ 自体の速度が $60.5 \mathrm{~km} / \mathrm{h}$ のきと，前後の区間

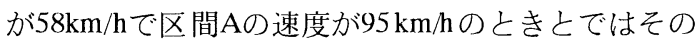
判定を変えた方が良いであろうということ，また， その区間Aの区間長が長いときや，インターチェン ジの存在や定期的工事のためあらかじめ渋滞の特幑 が分かっているようなとき等, むしろ柔軟に道路管 理者側の経験を導入した方が良い判定となる場合も 多いということである。このような場合においては， 各個別道路区間ごとに渋滞判定を制御するシステム の方が扱いやすいと思われるが，特に知覚渋滞定義 では $60 \mathrm{~km} / \mathrm{h}$ 以下の連続する区間全体の平均速度を求 めて判定する必要があるため各区間単位の状況変化 に対してむしろ鈍感となる傾向があり，柔軟に対応 できるものにはなっていないことである.

結局，上記のような状況之，幾つかの連続する区 間の渋滞状況を同時に加味して渋滞判定をするとい う知覚渋滞定義の基本（継続時間の考慮）とを考慮 して整理すると, 前後の渋滞意識の程度の状況を見 て，渋滞かどうかを判断するという以下のような新 たなシステムが想起される.

すなわち，前の区間の渋滞意識が ‘かなり渋滞” で, 判定対象区間Aが, “混雑”で, 次の区間が “渋 滞”ならば，判定対象区間Aは “淽滞” とするとか, 前の区間の渋滞意識が ‘混雑’ で, 判定対象区間 $\mathrm{A}$ 


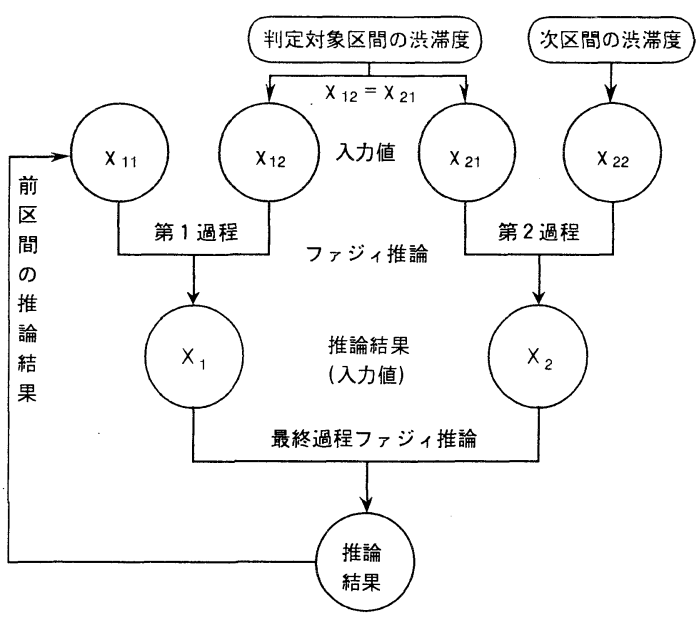

図一－フファジィ推論による渋滞判定過程

が, ‘混雑’ で，次の区間が ‘かなり渋滞”なら ば，判定対象区間Aを “渋滞”とするとかというよ うなシステムである。 そして，その区間ごとの渋 滞意識には，渋滞なしのレベル（アンケートにおい てだれも渋滞を意識しない速度とその継続時間の領 域）から，かなり渋滞（例えば $80 \%$ 以上の人が渋 滞と答えている速度とその継続時間の領域）という レベルまで利用しながら前後の状況を考慮して渋滞 判定する.

このようにもともとばらつきを持っている渋滞意 識をそのまま利用しながら，上記のようにして渋 帯なし，かなり渋滞，などのラベルに置き換えれば， 推論ルールにおけるラベルの意味（何\%の人がかな り渋滞と考えるかなど）が明確になるとともに，か つ上記で述べたような様々な交通状況之道路状況に 対して積極的に道路管理者の経験的知識を導入しや すくなり，より汎用性の高い渋滞判定モデルの構築 を可能にするように思われる.

さて, 上記 のような推論型 判定モデルを構築し ようとするとき, 道路管理者の経験的知識をルール 表によって扱うことができ, 渋滞意識というより曖 昧なデー夕を取り扱うときの適当な方法の一つとし てファジィ推論の適用が考えられるであろう。よっ て上記の理由から, 次章では渋滞判定モデルののファ ジィ推論の適用について分析することとする.

\section{4. ファジィ推論型渋滞判定モデル}

\section{(1)ファジィ推論の演算過程}

3.(4)で考察したような, 判定対象区間 $A$ とその前 後の区間の渋滞意識を利用して渋滞判定する構造を
そのまま導入したファジィ推論型渋滞判定モデルの 演算過程は図一6のようになる.

図に示すように, 本研究ではモデル構造を明確化 する意味から第 1 過程, 第 2 過程及び最終過程の 3 つの推論を組み合わせて渋滞判定を行う。すなわち， 第 1 過程では判定対象区間Aの渋滞意識（以下，渋 滞度）とその前区間の判定結果を入力值としてファ ジィ推論を行い，第 2 過程では判定対象区間 Aとそ の次区間の渋滞度をそれぞれ入力值としてファジィ 推論を行う。最終過程でそれぞれの推論結果を入力 值として最終的な判定対象区間Aの渋滞判定のため のファジィ推論を行う。このように第 1 過程，第 2 過程において前後区間の渋滞度を考慮して対象道路 区間の渋滞判定を行うのは，前章(4)で述べたよう に3章までの渋滞判定モデルが隣接道路区間の状況 を加味して渋滞判定する方法をとっているためであ り，したがって渋滞速度の継続時間を前後区間の速 度変化も考慮して算定する必要があるためである. 本モデルでは第 1，2 過程の推論においてそれぞれ 非ファジィ化されて求められた前後区間の渋滞度 (一 1〜1) を利用して, 最終過程において対象道路区 間の渋滞判定をすることになる。これらの各過程の ルールは 1 ゔの大きなルールへと統合することも可 能と思われるが, それによってルールの数は激増す るため, 逆にルール作成が煩雑でルール表が本来持っ ている直観的な性質を失うことになると考え，本研 究では以上の 3 つ過程で行うものとした。なお本 モデルでは各過程における 2 つの入值をもとに， 各過程においてそれぞれマムダ二(Mamdani)の推論 法 $^{12), 13)}$ によりファジィ推論を行うものとする. また, 第 1 過程, 第 2 過程の過程の入力值は次節で説明す る.

\section{(2)ファジィ推論の入力值}

入力値とは, 判定される区間の状態（渋滞又は解 消(非渋滞)の度合い) を示す数值である. 本ファジィ 推論型渋滞判定モデルでは，その入力值は渋滞解消 を考慮した渋滞の定義式をべースとして求める.し かし，これらの定義式を求める際にはもともとのデー 夕をあるカテゴリ一別（知覚渋滞定義では渋滞とは 言えない最低速度別）に平均值を出した後に定義式 を構築する手順を取っているので，個人個人の渋滞 意識のバラツキを考慮して渋滞度合いを示したもの とはなっていない，本研究では，このような渋滞意 識のバラツキを取り入れることも重要な目的である ので，次のように入力值を求めることにした．すな わち図ー7，8のように，それぞれの定義のもとと なっているアンケートの個人デー夕（知覚渋滞定義 


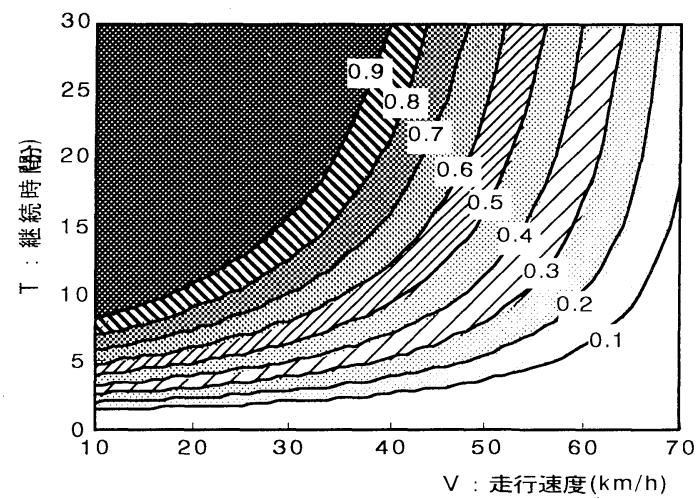

図-7 渋滞定義データの糸積相対度数(渋滞度)

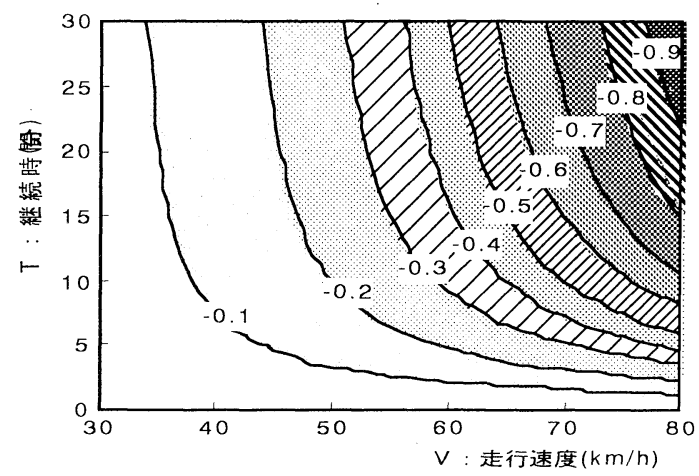

図-8 渋滞解消定義デー夕の累積相対度数 (渋滞解消度)

では1111件，渋滞解消定義では634件）を集計し直 し，各走行速度における渋滞を認識するまでの継続 時間，もしくは，渋滞解消を認識するまでの継続時 間の累積相対度数を求めた。

そしてこの走行速度一継続時間平面における累積 相対度数の值そのものを渋滞度（渋滞定義では正, 茨滞解消の定義では負の值）を示すものであると考 え，それを入力值とすることにした，すなわち，図 中の曲線及び数値の絶対值はその曲線上の累積相対 度数を示しており，たとえば，図一 7 の 0.4 の曲線 ではその曲線よりも上側の領域について渋滞之感じ る人が 4 割以上になることを示している，渋滞解消 の定義において数値を負の值としているのは次節の メンバーシップ関数作成の段階で理解しやすいため である.さて，ここで図一1の知覚渋滞定義を考え ると，それは図一 7 中の曲線の0.5 0.6の領域上に示 されることになる。これは，知覚渋滞定義では 5 割 以上の人が渋滞と感じる領域をあらかじめ渋滞と定 義しているためである. 綮密に 0.50 曲線に知覚渋 滞定義が一致しないのは, 集計方法の手順が図一7 と異なるためである. 図ー8についても同様なこと
が言える，渋滞度の利用方法は厳密には感知器デー 夕より得られた走行速度 $\mathrm{V}(\mathrm{km} / \mathrm{h})$ と継続時間 $\mathrm{T}$ (分)を 図ー7,8に当てはめてそのV,T座標上の渋滞と感じ るドライバーの割合を図から求めてそれを入力する ことになる. しかし，その入力值を簡便に求めるた めV, Tを変数として重回帰分析を行い，以下の回 帰式を得た。

$$
\begin{aligned}
& x_{a}=0.6681-0.0116 V+0.0203 T \\
& x_{b}=0.4431-0.0103 V-0.0148 T
\end{aligned}
$$

式(4)の $x_{a}$ は知覚渋滞定義における0〜 0 までの 渋滞度を示し, 式(5) $x_{b}$ は渋滞解消の定義における - 1 〜 0 までの渋滞解消度を示している. 相関係数 もそれぞれ $0.91,0.85$ と比較的高く，アンケートか ら得られたドライバーの渋滞意識はこの回帰式によ ってある程度近似できる。よって，これらの式より 求められる判定対象区間の渋滞 (解消) 度を入力值 としてファジィ推論を行う。なお，式(3),(4)は図を 利用して渋滞割合を求める作業を回帰式で代用する ものであり，また，図一7,8はV,Tに対して単調な（ 増加または減少）が保証される累積分布であるため， 式 (3), (4)の利用がもともとの渋滞意識分布を大きく 変えるものではないと考えられる。

\section{(3)メンバーシップ関数とルールの設定}

ここでは，まず基本的なメンバーシップ関数とル 一ルの設定例として，第 $1 ， 2$ 過程のルールの前件 部と後件部に利用するメンバーシップ関数を図ー9 のように，ルールを表一1のようにそれぞれの過程 で同じものを用いた，次いで最終過程のルールの前 件部と後件部に利用するメンバーシップ関数を図一 10 に，ルールを表－2 に示すように設定した．表 $-1 ， 2$ では基本ルールとして上三角形, 下三角形 で対称となっていることに特徴がある．実際にはこ のメンバーシップ関数はその $\mathbf{x}$ 軸が V-T 関係から得 られた渋滞度（-1 1) の值であり，渋滞と感じるド ライバーの割合を示していることを考慮しながら， 道路管理者の経験的知識をルール表の扱い易さ, 最 終的な判定結果を考慮して決定される。

ここで, 図表中のP.B., P.S., Z.O., N.S., N.B.はそれ ぞれかなり渋滞, 渋滞, 混雑, 解消, かなり解消亡 いう5つの指標のファジィ集合を示した。 また, 第 1，2 過程は $5 \times 5$ で 25 個のルールで，最終 過程はP.B., Z.O., N.B.の3つの指標において $3 \times 3$ の9個のルールでファジィ推論を行う. 最終的な判 定は，図一10上のZ.O.の領域一0.5 0.5の間において 


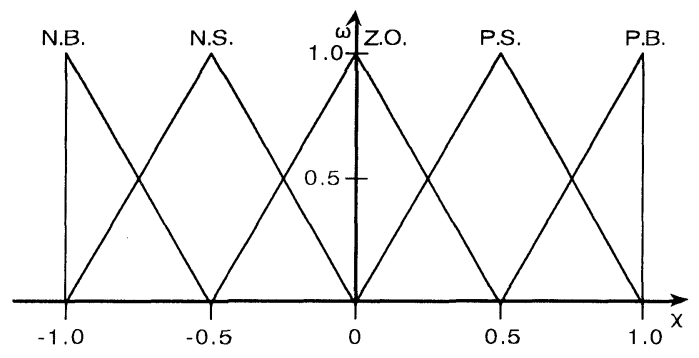

図ー9 メンバーシップ関数（第 1,2 過程）

\begin{tabular}{|c|c|c|c|c|c|}
\hline$A_{i 1}^{A_{i 2}}$ & P.B. & P.S. & Z.O. & N.S. & N.B. \\
\hline P.B. & $\begin{array}{l}\pi-\pi 1 \\
\text { P.B. }\end{array}$ & $\begin{array}{l}\pi-N_{2} \\
\text { P.B. }\end{array}$ & $\begin{array}{l}\text { N-N3 } \\
\text { P.S.S. }\end{array}$ & $\begin{array}{l}\pi-N 4 \\
\text { P.S. }\end{array}$ & $\begin{array}{l}n-115 \\
\text { Z.O. }\end{array}$ \\
\hline P.S. & $\begin{array}{l}n-16 \\
\text { P.B. }\end{array}$ & $\begin{array}{l}\text { n-ル7 } \\
\text { P.S. }\end{array}$ & $\begin{array}{l}n-\pi 8 \\
\text { P.S. }\end{array}$ & $\begin{array}{l}\pi-\pi 9 \\
Z .0 .\end{array}$ & $\begin{array}{l}\text { N.S. } \\
\text { N.S. }\end{array}$ \\
\hline Z.O. & $\begin{array}{r}n-\| 11 \\
\text { P.S. }\end{array}$ & $\begin{array}{r}\text { n-M12 } \\
\text { P.S. }\end{array}$ & $\begin{array}{l}N-\pi 13 \\
Z .0 .\end{array}$ & $\begin{array}{r}\pi-\pi 14 \\
\text { N.S. }\end{array}$ & $\begin{array}{r}\pi-\pi 15 \\
\text { N.S. }\end{array}$ \\
\hline N.S. & $\begin{array}{r}N-\pi 16 \\
\text { P.S. }\end{array}$ & $\begin{array}{r}\pi-\| 17 \\
Z .0 .\end{array}$ & $\begin{array}{l}\pi-\pi 18 \\
\text { N.S. }\end{array}$ & $\begin{array}{l}\pi-\pi 19 \\
\text { N.S. }\end{array}$ & $\begin{array}{r}\pi-\| 20 \\
\text { N.B. }\end{array}$ \\
\hline N.B. & $\begin{array}{r}\pi-\pi 21 \\
Z .0 .\end{array}$ & $\begin{array}{c}\pi-\| 22 \\
\text { N.S. }\end{array}$ & $\begin{array}{c}\pi-\| 23 \\
\text { N.S. }\end{array}$ & $\begin{array}{c}\|-\| 24 \\
\text { N.B. }\end{array}$ & $\begin{array}{r}\pi-\pi 25 \\
\text { N.B. }\end{array}$ \\
\hline
\end{tabular}

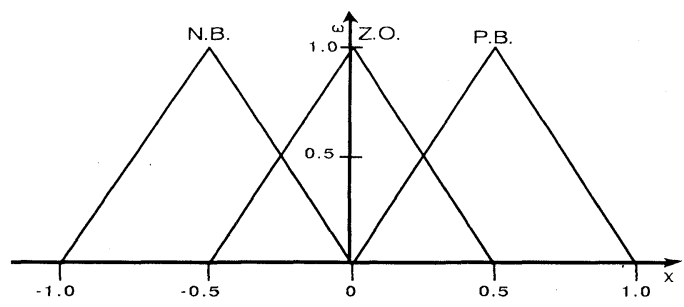

図-10 メンバーシップ関数（最終過程）

表一2 基本的なファジィルール (最終過程).

\begin{tabular}{|c|c|c|c|}
\hline 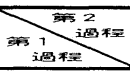 & P. B. & z.o. & N.B. \\
\hline P.B. & $\begin{array}{c}n-\pi \\
\text { P.B. }\end{array}$ & $\begin{array}{c}n-\mu z \\
P . B .\end{array}$ & $\begin{array}{l}\text { r n } 3 \\
\text { Z. } 0 .\end{array}$ \\
\hline Z.o. & $\begin{array}{l}\text { N-N } 4 \\
\text { P. } \mathrm{B} .\end{array}$ & $\begin{array}{l}\pi-\pi 5 \\
Z .0 .\end{array}$ & $\begin{array}{c}\text { n-ル } \\
\text { N.B. }\end{array}$ \\
\hline N.B. & $\begin{array}{l}n-s \\
Z .0\end{array}$ & 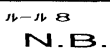 & $\begin{array}{c}\text { N-N9 } \\
\text { N.B. }\end{array}$ \\
\hline
\end{tabular}

チューニングの結果として境界值を設定し境界值よ りも出力が大きいとき渋滞と判定される.

なお，以下の図一 $11 ， 12$ の分析ではともに境界 值は，-0.27を採用した。

各過程におけるメンバーシップ関数として前件部, 後件部で同じものを利用するが，それは前件部，後 件部とも入力と出力が同じ渋滞度を表現することを 目的としているために，同じメンバーシップ関数を 利用した，ただし，それらは必ずしも同じである必 要はない.

\begin{tabular}{|c|c|c|c|c|c|c|c|c|c|c|}
\hline & A & B & $\mathrm{C}$ & D & E & F & G & $\mathrm{H}$ & & \\
\hline 距離 & 1.95 & 1.95 & & 1.55 & & 1.87 & & & & \\
\hline $6: 40$ & 97.4 & 98.9 & 98.6 & 75.8 & 68.0 & 80.4 & 70.0 & 73.1 & 72.3 & 73 \\
\hline & & & & 67.7 & & & & 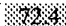 & 2 & \\
\hline & & & & & & & & & & \\
\hline 10 & 98. & 98.2 & 98.3 & 68. & 13 & 8 & $8 \%$ & 2 & 46 & 76 . \\
\hline & & 97.2 & & 46 & & & & . & 8 & \\
\hline & & & & & & & & & & \\
\hline $7: 40$ & 99.8 & 100.6 & 3.0 & w & 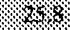 & 155 & 168 & 16.4 & \% & 76. \\
\hline & & & & 18. & & (3) & & \% & $8 \%$ & 69 \\
\hline & & 7.7 & & & $5 \%$ & & & & & \\
\hline & & 8.9 & & 4 & & - & 6 & $\%$ & 1. & 71. \\
\hline & & 7.8 & & & & 8 & & 838 & & 1 1. \\
\hline & & & & 10 & & 4. & & 4 & & \\
\hline & & \% & & $x$ & & 10 & & 26 & 8 & 3. \\
\hline & 97 & 97.5 & & & & $25 \%$ & & 4 & 4 & 3 \\
\hline & & & & & & 侳 & & 8 & 48 & 4 4. \\
\hline & & 8 & 8 & 11 & 8 & 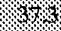 & 6 & $8 \%$ & 4 & \\
\hline & & & 8 & 680 & & 6 & & 60.2 & 30. & 69. \\
\hline & & & & & & & & & & \\
\hline & & & & & & $\%$ & & 64. & & 70. \\
\hline & & & 8 & $1 \%$ & & 58 & 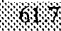 & 64 & 8 & 71. \\
\hline & & & & & & & & & & \\
\hline & & 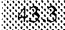 & & 63 & & & & 19 & 144 & 69. \\
\hline & & & & 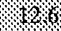 & 616 & & & 18 & 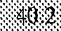 & $0 /$ \\
\hline & & & & & & & & s. & & \\
\hline & & 94 & & & & 688 & $1 / 1$ & 2. & 18 & \\
\hline & & & & & & & & 4 & & \\
\hline & & & & & & & & & & \\
\hline & & & & 3.2 & 24 & 1 & 18 & 164 & 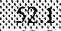 & 70 \\
\hline & & & & & & & & & & \\
\hline & & & & & & & & 65.8 & & \\
\hline & & & & & 48 & & & & & \\
\hline & & & & & & & & $7+1$. & & \\
\hline
\end{tabular}

図ー11 ファジィ推論型モデルによる判定結果 (チューニング前)

\section{(4)ファジィ推論型渋滞判定モデルによる}

\section{判定結果}

本ファジィ推論型渋滞判 定モデルによる判定結 果を図ー11に示し，3．の渋滞解消を考慮した渋 滞判定モデルによる判定結果（図 -5 ）と比較す る.

図－11を見ると，この分析で用いた基本ルール と基本的なメンバーシップ関数によってもおおよそ 安定した判定をしていることが分かる.しかし，図 -11は図－5と比べると特に区間B の8:40，9:10 9: 30 と区間Cの8:00で $80 \mathrm{~km} / \mathrm{h}$ 以上にも関わらず渋滞と 判定されているのがわかる. また，10:10 と10:30で は中抜けが見られやや不安定な結果となっている. これらの結果は，(1)表一1の基本ルールにおいて第 1 過程では前区間（Ai1）と判定対象区間（Ai2） の渋滞度が, 第 2 過程では判定対象区間 (Ai 1) と 次区間（Ai2）の渋滞度が，それぞれ同じ度合いと して推論結果に影響するような上・下三角形刘称の ルールとなっていること，(2)表一 2 も同様に機械的 に上・下三角形において対称に設定されたルールと なっていること，などに原因があると思われる。

そこで，上記の点に留意しながら図 -5 のよう な判定結果が得られるようにルール表のチューニ ングを行った，すなわち，第 1 過程，第 2 過程とも 
表ー3 チューニング後のルール（第 1 過程）

\begin{tabular}{|c|c|c|c|c|c|}
\hline$A_{i 1} A_{i 2}$ & P.B. & P.S. & Z.O. & N.S. & N.B. \\
\hline P.B. & $\begin{array}{l}\|-\| 1 \\
\text { P.B. }\end{array}$ & $\begin{array}{l}\|-\| 2 \\
\text { P.B. }\end{array}$ & $\begin{array}{l}n-\pi 3 \\
\text { P.S. }\end{array}$ & $\begin{array}{l}\text { N-N4} \\
Z . O .\end{array}$ & $\begin{array}{l}\pi-\pi 5 \\
N\end{array} . S$. \\
\hline P.S. & $\begin{array}{l}n-16 \\
\text { P.B. }\end{array}$ & $\begin{array}{l}n-\| 7 \\
\text { P.B. }\end{array}$ & P.S. & Z. Z.O. & N-ル10 \\
\hline Z.O. & $\begin{array}{c}\pi-\| 11 \\
\text { P.B. }\end{array}$ & $\begin{array}{l}\pi-\| 12 \\
\text { P.S. }\end{array}$ & $\begin{array}{l}\text { N-ル13 } \\
Z . O .\end{array}$ & $\begin{array}{l}N-\| 14 \\
\text { N.S. }\end{array}$ & $\begin{array}{l}n-\| 15 \\
\text { N.B. }\end{array}$ \\
\hline N.S. & $\begin{array}{l}\text { M-U16 } \\
\text { P.S. }\end{array}$ & $\begin{array}{l}\text { N-N17 } \\
\text { P.S. }\end{array}$ & N-M18. & $\begin{array}{c}\text { N.B. } \\
\text { N.B. }\end{array}$ & $\begin{array}{c}N-\| 20 \\
\text { N.B. }\end{array}$ \\
\hline N.B. & $\begin{array}{c}n-\| 21 \\
\text { P.S. }\end{array}$ & $\begin{array}{c}\|-\| 22 \\
Z .0 .\end{array}$ & $\begin{array}{l}\|-\| 23 \\
\text { N.S. }\end{array}$ & $\begin{array}{l}\text { N-124 } \\
\text { N.B. }\end{array}$ & $\begin{array}{c}n-125 \\
\text { N.B. }\end{array}$ \\
\hline
\end{tabular}

表ー4 チューニング後のルール（第 2 過程）

\begin{tabular}{|c|c|c|c|c|c|}
\hline$A_{i 1} A_{i 2}$ & P.B. & P.S. & Z.O. & N.S. & N.B. \\
\hline P.B. & $\begin{array}{l}\text { NM1 } \\
\text { P.B. }\end{array}$ & $\begin{array}{l}n-\| 2 \\
\text { P.B. }\end{array}$ & $\begin{array}{l}n-13 \\
\text { P.B. }\end{array}$ & $\begin{array}{l}n-144 \\
\text { P.S. }\end{array}$ & $\begin{array}{l}n-15 \\
\text { P.S. }\end{array}$ \\
\hline P.S. & $\begin{array}{l}\pi-\pi 6 \\
\text { P.B. }\end{array}$ & $\begin{array}{c}\|-\| 7 \\
\text { P.B. }\end{array}$ & $\begin{array}{l}n-\| B \\
\text { P.S. }\end{array}$ & $\begin{array}{l}n-119 \\
\text { P.S. }\end{array}$ & $\begin{array}{l}\text { «-M10 } \\
\text { Z.O. }\end{array}$ \\
\hline Z.O. & $\begin{array}{r}\text { N-ル11 } \\
\text { P.S. }\end{array}$ & $\begin{array}{r}\|-\| 12 \\
\text { P.S. }\end{array}$ & $\begin{array}{l}n-\| 13 \\
\text { Z.O. }\end{array}$ & $\begin{array}{c}N-\| 14 \\
\text { N.S. }\end{array}$ & $\begin{array}{r}\|-M 15 \\
\text { N.S. }\end{array}$ \\
\hline N.S. & $\begin{array}{c}\text { n-M16 } \\
\text { Z.O. }\end{array}$ & $\begin{array}{r}\pi-ル 17 \\
\text { Z.O. }\end{array}$ & $\begin{array}{l}N-\pi 18 \\
\text { N.S. }\end{array}$ & $\begin{array}{c}N-\pi 19 \\
\text { N.S. }\end{array}$ & $\begin{array}{c}n-\| 20 \\
\text { N.B. }\end{array}$ \\
\hline N.B. & $\begin{array}{r}1-121 \\
\text { Z.O. }\end{array}$ & $\begin{array}{c}\text { N-w22 } \\
\text { N.S. }\end{array}$ & $\begin{array}{l}n-123 \\
\text { N.S. }\end{array}$ & $\begin{array}{c}n-124 \\
\text { N.B. }\end{array}$ & $\begin{array}{r}\text { N-\|25 } \\
\text { N.B. }\end{array}$ \\
\hline
\end{tabular}

表ー5 チューニング後のルール（最終過程）

\begin{tabular}{|c|c|c|c|}
\hline 第1 2 & P.B. & Z.O. & N.B. \\
\hline P.B. & $\begin{array}{r}\text { ルール } 1 \\
\text { P.B. }\end{array}$ & $\begin{array}{r}\text { ルール } 2 \\
\text { P.B. }\end{array}$ & $\begin{array}{l}\text { ルール } 3 \\
\text { N.B. }\end{array}$ \\
\hline Z.O. & $\begin{array}{l}\text { ル-ル } 4 \\
Z .0 .\end{array}$ & $\begin{array}{l}\text { U-ル } 5 \\
\text { Z. } 0 .\end{array}$ & $\begin{array}{l}\text { N-ル6 } \\
\text { N.B. }\end{array}$ \\
\hline N.B. & $\begin{array}{l}\text { N-ル } 7 \\
\text { N.B. }\end{array}$ & $\begin{array}{l}N-ル 8 \\
\text { N.B. }\end{array}$ & $\begin{array}{c}\text { ルール } 9 \\
\text { N.B. }\end{array}$ \\
\hline
\end{tabular}

に前後区間よりも判定対象 区間の渋滞度がより推 論結果に反映されるようにし，また最終過程では第 1 過程の渋滞度の方が第 2 過程よりも推論結果によ り影響するようにルール表のチューニングを行い, そのルールを表ー3〜 5 に示した. このように チューニングを行ったルールを用いて推論した判 定結果を図-12に示す.

図一12を見ると図ー5とほぼ同じような結果に 推論されていることがわかる.これより，本ファジ イ推論型渋滞判定モデルは，3章の決定論的なモデ ルとは異なり，ルール表等のチューニングによりド ライバーや道路管理者の渋滞に対する認識や経験を 積極的に導入できることを示している．先にも述べ たとおり，3章までの渋滞判定モデルは道路線形, 速度データを入手する感知器の配置, オン・オフラ

\begin{tabular}{|c|c|c|c|c|c|c|c|c|c|c|}
\hline 盟N & A & B & C & D & E & $\bar{F}$ & $\bar{G}$ & $\mathrm{H}$ & & \\
\hline 距觹 & 1.95 & 1.95 & 2.00 & 1.55 & 4.14 & 1.87 & 1.55 & 2.23 & 2.03 & 1.90 \\
\hline $6: 40$ & 97. & 98.9 & 98.6 & 75.8 & 68.0 & 80.4 & 70.0 & 73.1 & 72.3 & 73. \\
\hline $6: 50$ & 99. & 100.4 & 99.7 & 67.7 & 68.2 & 69.3 & 69.2 & 72.4 & 8 & \\
\hline $7: 00$ & 95. & 96.2 & 93.6 & 4 & 859 & 66.7 & 66.7 & 63.1 & & \\
\hline 7:10 & 98.3 & 98.2 & 98.3 & 50 & 翟 & 468 & 58 & 然 & \% & \\
\hline $7: 20$ & 9 & 97.2 & 96.5 & (6) & 9 & ig & 94 & 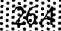 & 憏盘 & \\
\hline $7: 30$ & & 97.8 & 94 & 8 & (6) & 4 & 4 & 6 & I & \\
\hline $7: 40$ & 99.8 & 100.6 & 93.0 & 9 & 4 & 55 & & 696 & (3) & 76. \\
\hline & 98.4 & 98.6 & 93.8 & S & 69 & & & 68 & 119 & 69. \\
\hline 00 & 100. & 97.7 & 82.1 & & $4 t^{4}$ & 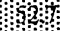 & 665 & 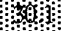 & $\mathrm{z}$ & 77 \\
\hline $8: 10$ & 100.8 & 98.9 & & 橉 & 45 & $j_{j} g \theta_{0}$ & 3 & 姲 & 6 & 71.1 \\
\hline $8: 20$ & 97.3 & 97.8 & (j) & 3 & 46 & 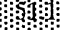 & 23 & 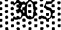 & 196 & 71. \\
\hline $8: 30$ & 963 & 97.2 & 6 & (1) & 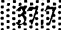 & 41 & 84 & S & 8 & 68.0 \\
\hline $8: 40$ & 99.6 & 99.7 & & 4 & 18 & 340 & 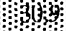 & 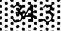 & 7 & 0.5. \\
\hline 8:50 & 97.4 & 97.5 & (3) & 9 & 倠 & (2) & 66 & 6 & $\gamma 2$ & 63. \\
\hline $9: 00$ & 96.1 & 96.2 & 13 & 80 & 99 & 69 & 29 & $1 \%$ & 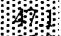 & 64. \\
\hline $9: 10$ & 96.0 & 97.0 & 45 & $\mathrm{z}$ & 8 & 3 & 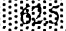 & 66 & 30 & 74. \\
\hline $9: 20$ & 92.5 & 93.5 & 47 & 细 & 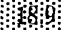 & 60 & 86 & 60.2 & 60.8 & 09. \\
\hline 9: & 95.5 & 82.4 & ing & 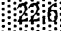 & 8 & 660 & 63 & 60.0 & 59.6 & .4 \\
\hline 9: & 99.4 & 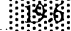 & 8 & 16 & $66_{3}$ & 72.0 & 58.8 & 64.8 & 55.2 & 70. \\
\hline & y. & 16 & 6 & 3 & & $S$ & 87 & 6443 & sid & 71.8 \\
\hline & 92.7 & $\%$ & (6) & 53 & 6 & 440 & 54 & 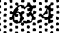 & 4 & 69.2 \\
\hline & 98.6 & 48 & 6 & $6 \%$ & $y^{2}$ & S & 544 & $x^{\prime}$ & 43 & 69.2 \\
\hline & 98.9 & 48 & 8 & (y) & 8 & 4 & 49 & 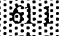 & (1) & 67. \\
\hline & 98.6 & 88.5 & (5) & 6 & (6) & 6 & 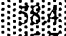 & 69 & 6 & 69. \\
\hline & 93.5 & 94.7 & 2 & 49 & 665 & $6 \%$ & 4 & 8 & $\alpha$ & 70. \\
\hline .50 & 97.5 & 96.5 & $g_{1}$ & $49^{5}$ & (j) & $44 t^{\prime}$ & 4 & 4 & \% & 66.2 \\
\hline & 95.6 & 96.8 & $8 y_{1}$ & 96 & 8 & $664^{1}$ & 36 & s & 4 & 69.9 \\
\hline & 97.1 & 96.7 & 89.2 & 3 & 16 & 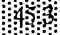 & 493 & 4 & 4 & 70.6 \\
\hline & 97.4 & 98.9 & 92.7 & 9 & 4 & 06 & 44 & 4 & 68.9 & 68. \\
\hline & 98.1 & 100.5 & 93.4 & 73.0 & 66 & 68.8 & 59.4 & 65.8 & 72.5 & 66. \\
\hline & 98.9 & 99.0 & 92.7 & 69.0 & to & 48 & 495 & 65.6 & 65.2 & 69 \\
\hline & 93.5 & 93.9 & 93.0 & 77.8 & 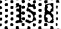 & 76.8 & 69.8 & 74.1 & 73.8 & 78. \\
\hline
\end{tabular}

図-12 ファジィ推諭型モデルによる判定結果

(チューニング後)

ンプ, ジャンクションなどの道路区間ごとに様々に 異なる道路状況, 'または首都圈, 大阪圈, 名古屋圈 といった地域によって異なるドライバーの意識など には対応できていないため, 実際の適用にあたって は道路管理者の知識・経験によるところが少なくな い.よって, 本研究で開発したファジィ推論型淽滞 判定モデルはドライバーの渋滞意識デー夕をより合 理的に扱い，また，一道路区間だけでは判定できな い渋滞判定をファジィ推論で結合することによって ドライバーや道路管理者の渋滞意識・経験を導入し やすいため，より汎用性の高いモデルといえる.

\section{5. 結論と今後の課題}

本研究で得られた結論はつぎのようになる.

(1)著者らが既に先行して研究していた人間の知覚 に基づく渋滞の定義では考慮されていなかった渋滞 解消についての定義づけを新たに行い, 渋滞解消定 義としての回帰式を得ることができた.

(2)渋滞解消の定義を人間の知覚に基づく渋滞の定 義に組み込んだ渋滞解消を考慮した橴滞判定モデル を構築したが，それによる判定結果と渋滞解消を導 
入していない従来モデルによる判定結果とを比較し たところ, 本モデルは従来モデルに比べ, より妥当 で安定した判定結果が得られることがわかった.

(3)渋滞解消を考慮した泚滞判定モデルにファジィ 推論を適用しファジィ推論型渋滞判定モデルを構築 したが, ファジィ推論を適用することでアンケート 回答のバラツキに伴う少数意見を考慮できることが わかった.

(4)また本モデルは, ルールの変更等によりドライ バーや道路管理者の渋滞意識・経験を積極的に導入 でき, 速度デー夕を入手する感知器の配置など各道 路区間によって異なる状況に対応可能であることが わかった.

本研究におけるファジィ推論のチューニングは主 にルール表によどまっており, 今後より良い精度を 目指すためにはメンバーシップ関数も含めたよりトー タルなチューニングを行うシステムの構築が必要で あろう. また, 本研究における渋滞意識の利用方法 やモデル形態, および, ファジィ推論の手法等につ いては, 基本的な構造を示したにとどまっているた め, それらの改良またはファジィ推論によらない別 な方法論も合わせてより効率のより方法を考案して いく必要があると思われる.さらに今後は，様々な 道路区間, むしくは感知器デー夕とは形式の異なる データでも判定可能か検討する必要があると思われ る.

\section{謝辞: 本研究の遂行にあたって, 日本道路公団名} 古屋管理局交通技術課およびシステム科学研 究所からは適切な助言やデー夕面で多大な援 助をいただきました、ここに深く感謝の意を 表します。

\section{参考文献}

1) 川添卓司, 酒井利忠 : 橴滞自動判定システム（暫定 型）に関する検討について，交通工学，Vol.22， No.2, pp. $9 \sim 15,1987$.

2) 日本道路公団名古屋管理局, 社団法人システム科学 研究所 : 名古屋管理局管内交通管制に関する研究 (そ の 3 ) 報告書, 1991.

3) 松井寛, 藤田素弘, 阿江章 : 人間の知覚に基づく高 速道路の渋滞評価とその情報提供方法に関す研究, 土木学会論文集, No.494/IV-24, pp127〜135, 1994.

4 ）越正毅、桑原雅夫, 赤羽弘和: 高速道路のトンネル, サグにおける渋滞現象に関する研究, 土木学会論文 集, No.458/NV-18, pp.65〜71, 1993.

5 ) 秋山孝正, 邵春福：ニューラルネットワークによる 交通渋滞量推定について, 土木計画学研究講演集, No.4(1), pp.417 424, 1991.

6) Mahmassani, H. S. and Jayakrishnan, R. : System Performance and User Response under Real-time Information in a Congested Traffic Corridor, Transpn. Res. -A, Vol.25A, No.5, pp.293 308, 1991.

7 ) 飯田恭敬, 内田敬, 宇野伸宏: 交通情報の効果を考 慮した経路選択行動の動的分析, 土木学会論文集,

No.470/IV - 20, pp.77 86, 1993.

8) Mahmassani, H. S. : Dynamic Models of Commuter Behavior:Experimental Investigation and Application to the Analysis of Planned Disruption, International Conference on Dynamic Travel Behavior Analysis Preprints-, 5-1, 1989.

9 ) 中川雄太郎 : ニューラルネット駆動型ファジィ推論 による所要時間推定, 土木計画学研究, 講演集17 pp197 200, 1995.

10）谷上敦亨 : 高速道路の溜带情報の評価に関する研究, 卒業論文, 1994.

11）谷上敦亨, 松井寛, 藤田素弘, 阿江章: 高速道路に おける渋滞情報の評価分析, 土木学会中部支部, 講 演概要集, pp.529〜530, 1994.

12）安信誠二: ファジィ工学, 昭晃堂, 1991

13）寺野寿郎：実用ファジィ制御技術, (社)電子情報通信 学会, 1991.

\title{
SPECIFICATION OF CONGESTED SECTIONS OVER AN EXPRESSWAY BY USING FUZZY REASONING
}

\author{
Hiroshi MATSUI, Motohiro FUJITA and Nobuyuki TANIUE
}

\begin{abstract}
Information provision about road congestion is one of the most important tools for relaxing congestion or drivers' irritation caused by congestion. Availability of information provision for drivers is basically dependent upon it's reliability. In this connection it is sometimes pointed out that there exists some gap between the congestion defined as a physical phenomenon and the congestion perceived by drivers. In our previous paper we proposed a general recognition rule of congestion on the basis of the drivers' perception. In this paper we expand this general recognition rule by considering individual deffernces of the drivers' perception with fuzzy reasoning and introducing the generation and dissolution mechanism of congestion as well.
\end{abstract}

